\title{
Analysis of the Causes and Prevention of the Postoperative Infectio of the Oral and Maxillofacial Region Tumor
}

\author{
Le Xiang, Wei Yu* \\ Department of stomatology, Renmin Hospital, Hubei University of Medicine \\ Address: Chaoyang District Road No. 39, Shiyan City, Hubei Prov, P.R. China, 442000 \\ *Corresponding author:hubeiwenbo@qq.com
}

Keywords: oral and maxillofacial region tumor, postoperative infection, factors; the countermeasures for prevention and cure

\begin{abstract}
The paper observes the factors related to the postoperative infection of the oral and maxillofacial region tumor and the countermeasures for prevention and cure. 45 postoperative infected persons (11.84\%) from 380 patients having been taken with the oral and maxillofacial region tumor surgery in the author's hospital from January, 2015 to July, 2017 were selected as the research objects. Then, the paper summarizes their infection factors, and puts forward the countermeasures for prevention and cure. Results show that: (1) The postoperative infection of the oral and maxillofacial region tumor was positively correlated to the age: when the patient was $<7$ years old and $>60$ years old, the occurrence rate was very high $(\mathrm{P}<0.05)$; (2) The infection was positively correlated to aspiration, invasive operations and immobilization $(\mathrm{P}<0.05)$; (3) The proper order of the occurrence rate of the infection site was lower in respiratory infection, wound infection and upper respiratory infection; (4) There were 28 cases infecting gram positive bacteria (62.22\%) and 17 cases infecting gram-negative bacteria (37.78\%); (5) The infection was positively correlated to the length of stay: the longer the length of stay, the higher the infection rate $(\mathrm{P}<0.05)$. In conclusion, the postoperative infection of the oral and maxillofacial region tumor is directly related to many factors, such as the patient' age, length of stay, aspiration, invasive operations and immobilization. In the clinic treatment, doctors shall assess the factors related to the infection comprehensively and choose the targeted countermeasures for prevention and cure to reduce the possibility of postoperative infection and provide assistance for prognosis.
\end{abstract}

\section{INTRODUCTION}

Most cases of the oral and maxillofacial region tumor are cancers and less are sarcomas, and most cancer cases are squamous-cell carcinoma, the next is glandular epithelioma, and it also contains other cancers, such as basal cell carcinoma, undifferentiated carcinoma and lymphoepithelioma. Most of these diseases happen at the exposed and obvious locations with obvious precancerous lesions, which create advantages [1] for the early discovery and determining the therapeutic schedule. The oral and maxillofacial region tumor surgery is the main method for curing this disease, which is taken to excise the local lesion radically to cure the patient's oral cavity and maxillofacial structure [2]. However, in recent years, there has been a clinical infection rate after treatment by this surgical method, which has influenced the therapeutic effect and prognosis severely. In this research, we focused on the factors related to the postoperative infection of the oral and maxillofacial region tumor and put forward some countermeasures for prevention and cure to provide reference for the prevention and cure scheme of postoperative infection. The summary is as follows:

\subsection{General data}

Choose 45 postoperative infected persons (11.84\%) from 380 patients having been taken with the oral and maxillofacial region tumor surgery in the author's hospital from January, 2015 to July, 2017 as the research objects. Inclusion criteria: the patients in this group had been taken with the oral and maxillofacial region tumor surgery in this hospital and all of them had infection indications. The 
group contained 28 male patients and 17 female patients. Among them, there were 7 patients who were $\leq 7$ years old, 18 patients of $7 \sim 60$ years old, and 21 patients who were $>$ years old; 10 cases whose lesion site was lip, 14 cases whose lesion site was cheek, 8 cases whose lesion site was tongue, 3 causes whose lesion site was parotid gland, 2 cases whose lesion site was submandibular region, 2 cases whose lesion site was soft palate, and 2 cases whose lesion site was buccal mucosa; among them, there were 33 cases with benign tumors and 12 cases with malignant tumors.

\subsection{Method}

Send the oral lesion samples of the suspicious persons suffering postoperative infection to the bacteria culture room for authentication, and measure and conclude the species of the pathogenic bacteria. Meanwhile, collect the clinical data of the patients who has been confirmed to be infected so as to analyze the factors for postoperative infection.

\subsection{Statistical method}

The data processing in the research was completed by the statistics software (SPSS21.0). The data having statistical difference between the samples and the data with correlation were expressed as $\mathrm{P}<0.05$; in which, the enumeration data were expressed with "rate" and the comparison is expressed with $\chi^{2}$ test.

\section{RESULTS}

\subsection{The relationship between the infection and the age}

The postoperative infection of the oral and maxillofacial region tumor is positively correlated to the age: when the patient is $<7$ years old and $>60$ years old, the occurrence rate is very high $(\mathrm{P}<0.05)$ (Table 1);

Table 1. The relationship between the infection and the age $[n(\%)]$

\begin{tabular}{cccc}
\hline Age & $\begin{array}{c}\text { Number of } \\
\text { patients }\end{array}$ & $\begin{array}{c}\text { Number of } \\
\text { the patients } \\
\text { infected }\end{array}$ & Infection rate \\
\hline$<7$ years old & 30 & 6 & 20.00 \\
$7 \sim 60$ years old & 269 & 18 & 10.65 \\
$>60$ years old & 81 & 21 & 25.93 \\
Total & 380 & 45 & 11.84 \\
\hline
\end{tabular}

Notes: comparing the infection rate of the patients who are $<7$ years old with that of $7 \sim 60$ years old, $\chi^{2}=6.47$, and $\mathrm{P}<0.05$. Comparing the infection rate of the patients who are $>60$ years old with that of $7 \sim 60$ years old, $\chi^{2}=8.42$, and $\mathrm{P}<0.05$.

\subsection{The relationship between the infection and the aspiration, invasive operations and immobilization}

All infected patients in this group have been taken with tracheotomy and other invasive operations, and all of them have lost the swallowing function in different degree with the behavior of aspiration. There were 5 patients suffering aspiration pneumonia, and the occurrence rate was $11.11 \%$. 35 infected patients (77.78\%) have been taken with the translation of the free tissue of carotid artery and have been immobilized completely for 1 to 2 weeks after treatment, which cause the patients to speak and have reflexive cough only.

\subsection{The relationship between the infection and the site and strain}

The proper order of the occurrence rate of the infection site is lower respiratory infection (24 cases, $53.33 \%$ ), wound infection (18 cases, $40.00 \%$ ), and upper respiratory infection (3 cases, 6.67\%); there are 28 cases infecting gram positive bacteria (62.22\%) and 17 cases infecting gram-negative bacteria $(37.78 \%)$ 
Table 2. The relationship between the infection and the site and strain $[n(\%)]$

\begin{tabular}{|c|c|c|c|c|c|c|c|c|c|c|c|}
\hline \multirow[b]{2}{*}{$\begin{array}{l}\text { Grou } \\
\text { ping }\end{array}$} & \multicolumn{5}{|c|}{ Gram positive bacteria (28) } & \multicolumn{6}{|c|}{ Gram-negative bacteria (17) } \\
\hline & $\begin{array}{l}\text { Staphylo } \\
\text { coccus } \\
\text { aureus }\end{array}$ & $\begin{array}{l}\text { Strepto } \\
\text { coccus }\end{array}$ & $\begin{array}{l}\text { Entero } \\
\text { coccus }\end{array}$ & $\begin{array}{l}\text { Coagula } \\
\text { se } \\
\text { negative } \\
\text { staphylo } \\
\text { coccus } \\
\end{array}$ & $\begin{array}{l}\text { Fun } \\
\text { gus }\end{array}$ & $\begin{array}{l}\text { Escher } \\
\text { ichia } \\
\text { coli }\end{array}$ & $\begin{array}{l}\text { Pseudo } \\
\text { monas } \\
\text { aerugi } \\
\text { nosa }\end{array}$ & $\begin{array}{l}\text { Bau } \\
\text { mani } \\
\text { i }\end{array}$ & $\begin{array}{l}\text { Klebsi } \\
\text { ella } \\
\text { pneum } \\
\text { oniae }\end{array}$ & $\begin{array}{l}\text { Aero } \\
\text { bacte } \\
\text { r } \\
\text { cloac } \\
\text { ae } \\
\end{array}$ & $\begin{array}{l}\text { Oth } \\
\text { ers }\end{array}$ \\
\hline $\begin{array}{l}\text { Num } \\
\text { ber }\end{array}$ & 16 & 5 & 1 & 2 & 4 & 6 & 3 & 3 & 2 & 2 & 1 \\
\hline $\begin{array}{l}\text { Perce } \\
\text { ntage }\end{array}$ & 57.14 & 17.86 & 3.57 & 7.14 & $\begin{array}{l}14 . \\
29 \\
\end{array}$ & 35.29 & 17.65 & 17.65 & 11.76 & 11.76 & $\begin{array}{c}5.8 \\
8 \\
\end{array}$ \\
\hline
\end{tabular}

2.4 The relationship between the infection and the length of stay

The infection is positively correlated to the length of stay: among the 100 patients who were hospitalized for less 15d, there were 6 infected penitents (6.00\%); among the 191 patients who were hospitalized for 15 30d, there were 21 infected patients (10.99\%); among the 89 patients who were hospitalized for more than 30d, there were 18 infected patients (20.22\%); the results show that the longer the length of stay, the higher the infection rate; taking the patients who were hospitalized for less $15 \mathrm{~d}$ as the control group, the infection rate of the patients who were hospitalized for 15 30d is $\chi^{2}=3.41(\mathrm{P}<0.05)$, and that more than $30 \mathrm{~d}$ is $\chi^{2}=6.42(\mathrm{P}<0.05)$.

\section{DISCUSSION}

\subsection{Factor analysis}

The pathogenic factors of the oral and maxillofacial region tumor are positively related to the textural anomaly of blood vessel and lymph gland. There is obvious formation of blood vessel and aggregation of mast cells at the infected part, both of which cannot degenerate automatically [4]. The disease is accompanied with obvious precancerous lesions, which doesn't only provide important conditions for early treatment, but also shows the main pathological changes for the possible cancer, such as the obvious leukasmus, chap, chronic ulcer and pigmented spots, but not all lesions will be evolved to be cancers. Besides the underlying pathological factors, other comprehensive factors also are the causes, but finally, only a few lesions will be evolved to be cancers. Therefore, in order to prevent the lesions from being evolved to be cancers, while curing the above lesions, we need to eliminate various chronic stimulating factors, in which, the postoperative infection of oral and maxillofacial region tumor is an important factor. The occurrence of postoperative infection is more related to the decline of the patient's own immunity and the increase of the bacteria caused by surgical wound pollution. The research results show that the patients who are less than 7 years old and more than 60 years old are the main infected objects, which means the patients' own immunity is positively related to the infection. In addition, aspiration, invasive operations and immobilization also will increase the infection rate, and the longer the length of stay, the higher the infection rate, which is consistent with Sun Zhenlong's research report [5]. Besides, usually the quantity of bacteria to cause infection is $>105 / \mathrm{g}$, so the daily secreta at the patient's partes oralis is one of important factor for infection; the antibiotics has been abused in recent years, so part of bacteria have strong drug resistance, which also is a potential infection factor [6].

\subsection{Analysis of the countermeasures for prevention and cure}

After summarizing the infection factors, the author puts forward the following countermeasures for prevention and cure: (1) control the origins of bacteria before and during the operation: in the condition of keeping the good therapeutic effect, shorten the preoperative preparation time and the length of stay as far as possible, reinforce the nutritional support for the patients during the perioperative period, improve the patients' immunity by daily targeted nutritional support, encourage penitents not to eat at the early stage, give some suggestions to their diet schemes, give compound antibiotics to patients $1 \mathrm{~d}$ before operation to gargle, and clean the whole body after treatment to minimize the origins of bacteria for postoperative infection. Moreover, when using the drugs, test the 
patients' drug-resistance bacteria, follow the doctor's advice for medication, control the dose of antibiotics strictly. Finally, observe the sterile operations strictly before and during the operation and during the care process of the operation, and all surgical instruments and articles to be used shall be checked and sterilized strictly [7]. (2) Postoperative wound care: the wounds of the patients after the oral and maxillofacial region tumor surgery mainly at maxillofacial region and oral cavity. Because of the big wounds and the operative treatment method, patients often feel painful obviously during the perioperative period, and the self-cleaning function of the oral cavity is weakened with it. Therefore, the targeted oral care during the perioperative period is significant. Meanwhile, doctors shall guide the patients to maintain a good oral environment everyday, observe the surgical incision carefully after operation, and especially when changing the dressing, they shall inspect the local performance of the incision carefully. When finding an infected suspicious person, inform the doctor immediately and get some dressing as sample for bacterial culture, and then give targeted treatment to it.

\subsection{Conclusions}

The postoperative infection of the oral and maxillofacial region tumor has a direct relation with many factors, such as the patient' age, the length of stay, aspiration, invasive operation and immobilization, so in the clinic treatment, we need to assess the factors related to the infection comprehensively. Because the cases and research time were limited, and the indexes were less, the research had some defects, but the research results were very reliable and they were consistent with that of clinic and other researches. The discussion on the postoperative infection of the oral and maxillofacial region tumor is the key to reduce and prevent the occurrence rate of the disease, so the author suggests researching the factors with large samples, long time and many indexes, and selecting the correct targeted countermeasures for prevention and cure to reduce the possibility of postoperative infection and provide assistance for prognosis.

\section{REFERENCES}

[1] Yang WB, Li CJ, Li LJ, Sheng SR, Qi SQ, Pan J.“Postoperative Infection Bacteria and Drug Resistance in Patients with Oral and Maxillaofacialtumors”, Shanghai Kou Qiang Yi Xue,vol.04,pp.584-588,2015.

[2] Raczyńska-Witońska G, Witoński D, “Fungi and Bacteria as a Pathogenic Factor in Wound Healing in Patients after Orthopaedic Surgeries”,Ortop Traumatol Rehabil, vol.11, pp. 646-649,2016.

[3] Khoruk SM, Krechikov VA. "Results of Using the Combined Medicine Bacitracin + Neomycin in the Postoperative Period after Cosmetic Surgery Correcting Maxillofacial Soft Tissue Defects", Khirurgiia (Mosk), vol. 12, pp.47-50,2008.

[4] Senpuku H, Tada A, Uehara S, Kariyama R, Kumon H.“Post-operative Infection by Pathogenic Micro- organisms in the Oral Cavity of Patients with Prostatic Carcinoma”, J Int Med Res,2006.

[5] Assael LA. “Nosocomial Infection and Fomites in Oral and Maxillofacial Surgery Practice”, $J$ Oral Maxillofac Surg, vol.02, pp.889-890,2005.

[6] Obremskey WT, Schmidt AH,OToole RV,DeSanto J,“A Prospective Randomized Trial to Assess Oral Versus Intravenous Antibiotics for the Treatmentof Postoperative Wound Infection After Extremity Fractures (POvIV Study)”, J Orthop Trauma,vol.05,pp.32-38,2017.

[7] Woo BH, Kim DJ, Choi JI, “Oral Cancer Cells Sustainedly Infected with Porphyromonas Gingivalis Exhibit Resistance to Taxol and Have Higher Metastatic Potential”, Oncotarget,2017. 